Acta medico-historica Rigensia (2005) VII: 427-428

DOI: 10.25143/amhr.2005.VII.38

ACTA MEDICO - HISTORICA RIGENSIA VII (XXVI)

\title{
IN MEMORIAM ALEXANDER ABRAMOVICH GRANDO
}

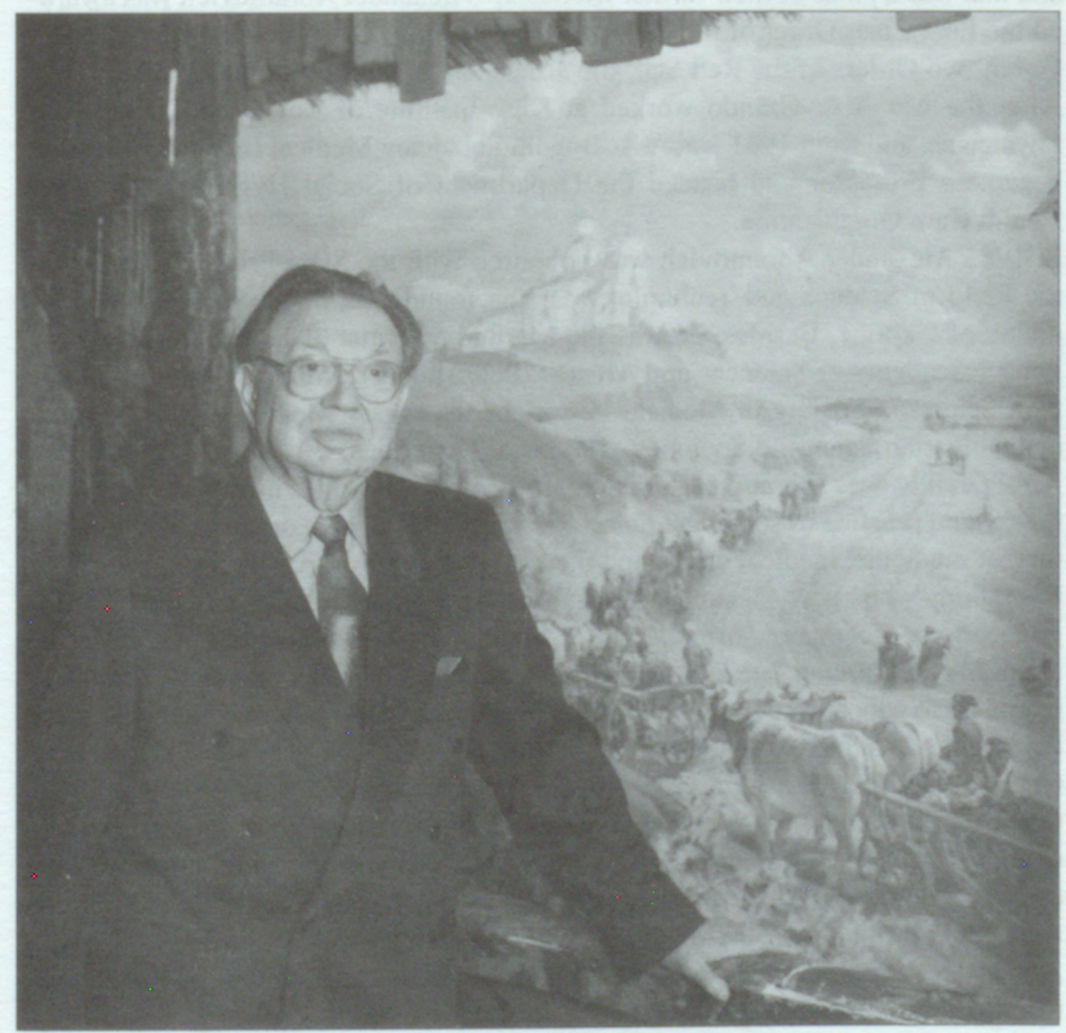

A.A. Grando (1919-2004)

It was on July 17, 2004, that Alexander Abramovich Grando passed away. A man who intended to create National Museum of Medicine in Ukraine md realized his idea is no more. Alexander Abramovich was a heart and intellect of the team which built and developed the Museum with him. He headed the Museum till his last day. Despite his age, Alexander Abramovich had a lot of ideas and plans, met readily 
with correspondents from papers and journals, took part in broadcasts and telecasts.

A.A. Grando was born on October 10,1919, in the town of Mogilev-Podolsky of Vinnitsa region. In 1937, he entered Kiev Medical Institute, and with beginning of the Great Patriotic war he, being a student, was sent to the courses of militarymedical training and then to front. He took part in Stalingrad Battle, and the war end found him in Eastern Prussia. He met N.M. Amosov on the road of the war and that was a pulse of their further friendship. Alexander Abramovich was awarded the First Class Order of the Patriotic war, the Third Class Bogdan Khmelnitsky Order, two Orders of the Red Star, the order For Services and many medals.

After the war A.A. Grando worked at Kiev Institute of Advanced Training for Physicians, and from 1961 - at A.A. Bogomoletz Kiev Medical Institute, where he became a professor and headed the Department of Social Hygiene and Public Health Care Organization.

In 1983 Alexander Abramovich was honoured with the State Prize of Ukraine in the Field of Science and Technology for the foundation of the Museum of Medicine of Ukraine. Besides, he was the Merited Scientist of Ukraine, Member of Peter I Academy of Sciences and Arts (St.-Petersbourg), Honorary head of Ukrainian Scientific Society of Medical Historians, Honorary Member of the Russian and Bulgarian Scientific Societies of Medical Historians.

A.A. Grando was the author of above 150 scientific works in the problems for theory and practice of social medicine and public health care organization, the history of medicine, medical ethics and medical deontology.

Everybody who knew Alexander Abramovich will remember him as a gifted pedagogue, a good company, original writer and essayist, keen historian who worried about his Motherland fate and worked for its future. Honesty, openness, criticism, readiness to support any man not indifferent to the history of home medicine were his brightest features.

One can say that he was a knight of the history of medical science. Professor Grando got to know representatives of several generations and schools in medicine, people from different countries during his life. And he came to terms with everybody devoted to their profession. It was owing to A. Grando that the Museum was recognized all over the world, it was often called Grando's museum.

Alexander Abramovich always tried to impulse people with proud for their country, to know as much as possible about contemporaries, and retain good memory of those which are gone. Let us also retain good memory, of the unselfish soul of this man, his deeds and hopes...

Collective of the National Museum

of Medicine of Ukraine,

Editorial Council of Journal Agapit 